\title{
Identification of Biochemical Variation in Alternaria Isolates of Onion Plant
}

\author{
Srujani Behera $^{1 *}$, Subrata Dutta $^{2}$ and Srikanta Das ${ }^{2}$ \\ ${ }^{1}$ Department of Plant Pathology, College of Agriculture, Bhawanipatna, \\ OUAT, Odisha 766001, India \\ ${ }^{2}$ Department of Plant Pathology, Faculty of Agriculture, Bidhan Chandra Krishi \\ Viswavidyalaya, Mohanpur, Nadia-741252, West Bengal, India
}

*Corresponding author

\section{A B S T R A C T}

\section{Keywords}

Onion Alternaria,

Isoenzymes, $\alpha-$

esterase and $\beta$ -

esterase

\section{Article Info}

Accepted:

04 June 2018

Available Online:

10 July 2018
Biochemical variability among the 15 isolates of Alternaria isolates from different locations of West Bengal was investigated in respect of isozyme to observe the polymorphism among the isolates. Electrophoretic separation of the extracts was carried out on native PAGE following the procedure and gels were stained for different enzymes. The activity of $\alpha$ - esterase produced distinctive bands that were dark brown, whereas the activity of $\beta$ - esterase produced bands that were dark pink so that $\alpha$ - esterase and $\beta$ esterase were scored very easily. Two separate runs were conducted to determine reproducibility of the bands and to calculate the relative mobility $(\mathrm{Rm})$. Values of each of the isozyme based on the presence or absence matrix of the bands of each isolate. Positive activity was observed for both $\alpha$ - and $\beta$ - esterase. $\alpha$ - esterase enzyme showed the highest enzyme activity in terms of maximum numbers of banding loci among the two isozymes tested.

\section{Introduction}

Onion (Allium cepa L.) rightly called as "queen of kitchen" is one of the oldest known and an important vegetable crop grown in India (Selvaraj, 1976). Onion is susceptible to numerous foliar, bulb and root pathogens that reduce yield and quality (Cramer, 2000). Excessive rains, humidity, temperature, pests and disease are critical factors of risk to onion cultivation. Purple blotch of onion caused by A. porri (Ellis) Ciff. is one of the most serious disease in India (Gupta et al., 1986; Tripathi et al., 2008; Ramjegathesh et al., 2011). The yield losses of bulb and seed crop in India due to this disease under favourable conditions are upto 97\% (Gupta and Pathak, 1998; Lakra, 1999).

As a genus, Alternaria is a diverse and ubiquitous group of fungi having a high degree of variability in spore shape and size, pathogenicity and sporulation and unambiguous species boundaries (Chethana et $a l, 2018)$. Isozyme analysis is one of the most useful methods in resolving the existence of 
variation among the species. Isomer pattern of Alternaria spp. isoenzymes viz. $\alpha$ - esterase $(\alpha$-Est) and $\beta$-esterase ( $\beta$-Est) were studied to understand the biochemical variation among different isolates.

\section{Materials and Methods}

\section{Materials and methods}

\section{Collection and isolation of pathogen}

Leaves of onion infected by pathogen showing typical dark brown, circular to irregular spots were collected from different locations of West Bengal and fifteen A. porri isolates was isolated from these infected leaves by standard tissue isolation technique in the laboratory. The infected leaf bits will be surface sterilized with $0.1 \%$ mercuric chloride $\left(\mathrm{HgCl}_{2}\right)$ for 30 seconds and repeatedly washed separately in sterilized distilled water to remove the traces of mercury if any and then transferred to sterilized Petri plates (1-2 leaf bits per Petri dish) containing potato dextrose agar (PDA). The Petri plates will be incubated at room temperature $\left(27 \pm 1^{\circ} \mathrm{C}\right)$ and observed periodically for the growth. Bit of fungal growth developed from the infected tissue was transferred to PDA slants. Then the mycelial tip or single spore isolation will be done for purification of the pathogen. Then such slants with pure culture will be used for further studies.

\section{Biochemical variability}

Studies on isoenzyme profiles of Alternaria isolates by polyacrylamide gel electrophoresis method

Isozyme analysis is one of the most useful methods in resolving the existence of variation among the species. Isomer pattern of Alternaria spp. isoenzymes viz. $\alpha$ - esterase $(\alpha$-Est) and $\beta$-esterase $(\beta$-Est) were studied to understand the biochemical variation among different isolates. Electrophoresis of esterase isoenzyme was done in $7.5 \%$ gel according to the method proposed by Kahler and Allard (1970).

\section{Preparation of buffer solution}

a) Buffer solution $\mathrm{A}$

Tris (Hydroxy methyl amino methane) $\quad 0.8 \mathrm{~g}$

Citric acid $200 \mathrm{mg}$

Double distilled water $100 \mathrm{ml}$

$\mathrm{pH}$ was adjusted to

b) Tank electrode buffer (B)

Lithium hydroxide

$1.2 \mathrm{gm}$

Boric acid

$11.9 \mathrm{gm}$

Double distilled water

$1000 \mathrm{ml}$

Adjusted to $\mathrm{pH}$

c) Buffer C

Tris (Hydroxy methyl amino methane) 310mg

Citric acid

$80 \mathrm{mg}$

Double distilled water

$1000 \mathrm{ml}$

Adjusted to $\mathrm{pH}$

8.2

d) Buffer D

Tris (Hydroxy methyl amino methane) $600 \mathrm{mg}$ Double distilled water

$100 \mathrm{ml}$

e) Gel casting solution ( $7.5 \%$ gel $)$

Acrylamide

$3.25 \mathrm{gm}$

Bis-acrylamide

$0.067 \mathrm{gm}$

Double distilled water

$50 \mathrm{ml}$

f) Amonium persulphate solution (APS)

Amonium persulphate solution (APS) $250 \mathrm{mg}$

Double distilled water $5 \mathrm{ml}$

TEMED (N,N,N,N(Tetramethyl

ethylene diamine)

This solution was freshly prepared on the day of use

g) Loading buffer

Bromophenol blue (5\%) and Glycerol 1: 2 


\section{Preparation of staining solution}

Fast blue R R salt

$\alpha$ or $\beta$-naphthyl acetate

Buffer (D)

$100 \mathrm{mg}$

$0.004 \mathrm{~g}$

$100 \mathrm{ml}$

\section{Extraction of enzyme from isolates of Alternaria spp.}

Enzymes were extracted individually from different isolates. $500 \mathrm{mg}$ fungal mat freshly harvested from actively growing culture of Alternaria isolates were crushed with $1 \mathrm{ml}$ enzyme extraction buffer $(\mathrm{pH}-7)$ in a precooled mortar and pestle at ${ }^{0} \mathrm{C}$. The resulting homogenate mixture was centrifuged at 14,000 r.p.m for $20 \mathrm{mins}$ at $4^{\circ} \mathrm{C}$ in Heraeus Biofuge (Stratos, Biorad), a temperature controlled centrifuge machine. The supernatant was collected and kept in the refrigerator at $4^{\circ} \mathrm{C}$ and used as enzyme source.

\section{Gel casting}

$7.5 \%$ (size $10 \mathrm{~cm} \times 10 \mathrm{~cm}$ micro) gel was prepared by mixing $27 \mathrm{ml}$ buffer (B) and $3 \mathrm{ml}$ buffer (C with $3.25 \mathrm{~g}$ of acrylamide, $0.067 \mathrm{~g}$ bis-acrylamide. After thorough mixing, $5 \mathrm{ml}$ of ammonium persulphate (APS) solution and $20 \mu 1$ TEMED (N, N, N', N'tetramethylethylene diamine) was added to it. Then quickly pour the gel solution in the gap between the two glass plates and set the comb by inserting it between the glasses and left it to solidify. After solidification, the samples of different isolates were loaded separately in different lanes and the gel was run at 80 volt for $2.5-3 \mathrm{~h} 4^{0} \mathrm{C}$.

\section{Staining of gel}

a) $\alpha$ esterase gel

On completion of the gel run, the gel was carefully removed from and placed into the staining solution $(100 \mathrm{ml}$ of buffer D) prepared at the time of use containing $100 \mathrm{mg}$ Fast Blue RR salt and $0.004 \mathrm{~g} \alpha$-napthyl acetate(dissolved in $1 \mathrm{ml}$ of ethyl alcohol). The gel was incubated at $28{ }^{\circ} \mathrm{C}$ in dark condition for 30 min with occasional shaking for development of band. After development of the bands, the gel was washed with distilled water. The gel was transferred and photographed. The Rm (Relative mobility) values of band(s) were estimated. The banding patterns or the zymograms so obtained were analyzed based on procedure given for identifying the putative loci as described by Wendem and Weeden (1989). The band length was measured and relative mobility ( $\mathrm{Rm})$ value was calculated using the following formula.

$$
\begin{aligned}
& \text { Distance of the band from origin } \\
& \mathrm{Rm} \text { value = --------------------1}
\end{aligned}
$$

b) $\beta$-esterase gel

On completion of the gel run, the gel was carefully separated and placed in $100 \mathrm{ml}$ of buffer (D), containing 100mg Fast Blue RR salt and $0.004 \mathrm{~g} \quad \beta$-napthyl acetate (dissolved in $1 \mathrm{ml}$ of ethyl alcohol) for staining. The gel was incubated at $28{ }^{\circ} \mathrm{C}$ in dark condition for 30 min with occasional shaking for development of band. After development of the bands, the gel was washed with distilled water. The gel was transferred and photographed. The Rm (Relative mobility) values of band(s) were estimated as mentioned before.

\section{Results and Discussion}

Biochemical variability among the 15 isolates of Alternaria isolates from different locations was also investigated in respect of isozyme to observe the polymorphism among the isolates and the results are discussed below. 


\section{Alpha esterase isozyme}

Electrophoretic separation of enzymes, which exploits the polymorphism of detected isozyme forms, is an important biochemical/ molecular technique that have been widely used to generate a large number of markers for the assessment of genetic diversity in fungi. An experiment was conducted to study the biochemical variability among Alternaria isolates collected from different locations based on $\alpha$-esterase profiling.

Electrophoretic separation of the extracts was carried out on native PAGE following the procedure described by Davis (1964) and gels were stained for different enzymes. The activity of $\alpha$ - esterase produced distinctive bands that were dark brown, whereas the activity of $\beta$ esterase produced bands that were dark pink so that $\alpha$ - esterase and $\beta$ - esterase were scored very easily. Two separate runs were conducted to determine reproducibility of the bands and to calculate the relative mobility $(\mathrm{Rm})$. Values of each of the isozyme based on the presence or absence matrix of the bands of each isolate. Positive activity was observed for both $\alpha$ - and $\beta$ - esterase. $\alpha$ - esterase enzyme showed the highest enzyme activity in terms of maximum numbers of banding loci among the two isozyme tested. All the isolates have different banding pattern and maximum locii 7 was observed on isolate $\mathrm{AP}_{8}$. Five isolate produced 6 banding patterns $\left(\mathrm{AP}_{1}, \mathrm{AP}_{2}, \mathrm{AP}_{4}, \mathrm{AP}_{7}\right.$ and $\mathrm{AP}_{15}$ ) and another five isolate produced 5 banding patterns $\left(\mathrm{AP}_{5}, \mathrm{AP}_{11}, \mathrm{AP}_{12}, \mathrm{AP}_{13}\right.$ and $\mathrm{AP}_{14}$ ). Four isolate produced 4 banding patterns $\left(\mathrm{AP}_{3}, \mathrm{AP}_{6}, \mathrm{AP}_{9}\right.$ and $\left.\mathrm{AP}_{10}\right)$. It was also observed that all the 15 isolates have one loci of $\mathrm{Rm}$ value 0.31 . Among the 15 isolates, 12 isolates produced one loci on the $\mathrm{Rm}$ value of 0.29 except $\mathrm{AP}_{5}, \mathrm{AP}_{6}$ and $\mathrm{AP}_{4}$. Similarly all the isolates produced another loci of $\mathrm{Rm}$ value 0.32except isolate $\mathrm{AP}_{5}, \mathrm{AP}_{6}, \mathrm{AP}_{2}$ and $\mathrm{AP}_{1}$. Among the 15 isolates, 9 isolates also produced another loci of $\mathrm{Rm}$ value of 0.33 except $\mathrm{AP}_{9}$,
$\mathrm{AP}_{10}, \mathrm{AP}_{15}, \mathrm{AP}_{7}, \mathrm{AP}_{3}, \mathrm{AP}_{2}$ and $\mathrm{AP}_{1}$. Similarly the 9 isolates of among 15 isolates, also produced another loci of $\mathrm{Rm}$ value 0.36 except $\mathrm{AP}_{11}, \mathrm{AP}_{12}, \mathrm{AP}_{13}, \mathrm{AP}_{14}, \mathrm{AP}_{6}$ and $\mathrm{AP}_{8}$. The two isolates $\mathrm{AP}_{5}$ and $\mathrm{AP}_{15}$ also produced one loci of $\mathrm{Rm}$ value 0.40. 6 isolates $\left(\mathrm{AP}_{15}, \mathrm{AP}_{7}, \mathrm{AP}_{8}\right.$, $\mathrm{AP}_{4}, \mathrm{AP}_{2}$ and $\mathrm{AP}_{1}$ produced another bands on $\mathrm{Rm}$ value of 0.41 . Isolates $\mathrm{AP}_{6}, \mathrm{AP}_{8}, \mathrm{AP}_{2}$ and $\mathrm{AP}_{1}$ produced another $\mathrm{Rm}$ value of 0.42 . The highest $\mathrm{Rm}$ value 0.51 was observed on 7 isolates were $\mathrm{AP}_{5}, \mathrm{AP}_{6}, \mathrm{AP}_{7}, \mathrm{AP}_{8}, \mathrm{AP}_{4}, \mathrm{AP}_{2}$ and $\mathrm{AP}_{1}$. This indicated that these 15 isolates were different in isozyme pattern of $\alpha$ - esterase (Fig. 1).

A dendrogram was generated by UPGMA clustering as presented in the Figure 2. This dendrogram identified three major clusters with $25 \%$ euclidean distance. One cluster (group I) comprised of seven isolates $\mathrm{AP}_{14}, \mathrm{AP}_{15}, \mathrm{AP}_{10}$, $\mathrm{AP}_{1}, \mathrm{AP}_{2}, \mathrm{AP}_{13}$ and $\mathrm{AP}_{7}$ while other cluster (group II) comprised of four isolates $\mathrm{AP}_{8}, \mathrm{AP}_{12}$, $\mathrm{AP}_{9}$ and $\mathrm{AP}_{11}$ and another cluster (group III) comprised of four isolates $\mathrm{AP}_{5}, \mathrm{AP}_{6}, \mathrm{AP}_{3}$ and $\mathrm{AP}_{4}$. Group I was further sub-clustered into two groups, of which first sub-cluster (group IA) had three isolates $\mathrm{AP}_{14}, \mathrm{AP}_{15}$ and $\mathrm{AP}_{10}$ in which $\mathrm{AP}_{14}$ and $\mathrm{AP}_{15}$ showed their close relationship and isolate $\mathrm{AP}_{10}$ was in separate individual cluster. Second sub-cluster (group IB) included four isolates $\mathrm{AP}_{1}, \mathrm{AP}_{2}, \mathrm{AP}_{13}$ and $\mathrm{AP}_{7}$. Group $\mathrm{IB}$ was again sub divided into two clusters, i,e group IBa and group IBb. Group $\mathrm{IBa}$ comprised of three isolates $\mathrm{AP}_{1}, \mathrm{AP}_{2}$ and $\mathrm{AP}_{13}$ and group $\mathrm{IBb}$ had only one isolate $\mathrm{AP}_{7}$. Isolate $\mathrm{AP}_{13}$ was in separate individual cluster while isolates $\mathrm{AP}_{1}$ and $\mathrm{AP}_{2}$ shared very close relationship. Group II was belongs to subclustered into two, of which first sub-cluster (group IIA) had two isolates $\mathrm{AP}_{8}$ and $\mathrm{AP}_{12}$ which are closely related while the second subcluster (group IIB) had also two isolates $\mathrm{AP}_{9}$ and $\mathrm{AP}_{11}$ which are also closely related. Group III was comprised of four isolates $\mathrm{AP}_{5}, \mathrm{AP}_{6}$, $\mathrm{AP}_{3}$ and $\mathrm{AP}_{4}$ which were closely related with each other. 
Fig.1 Zymogram of Alpha esterase isozyme of Alternaria isolates AP9 AP10 AP11 AP12 AP13 AP14 AP15 AP5 AP6 AP7 AP8 AP4 AP3 AP2 AP1

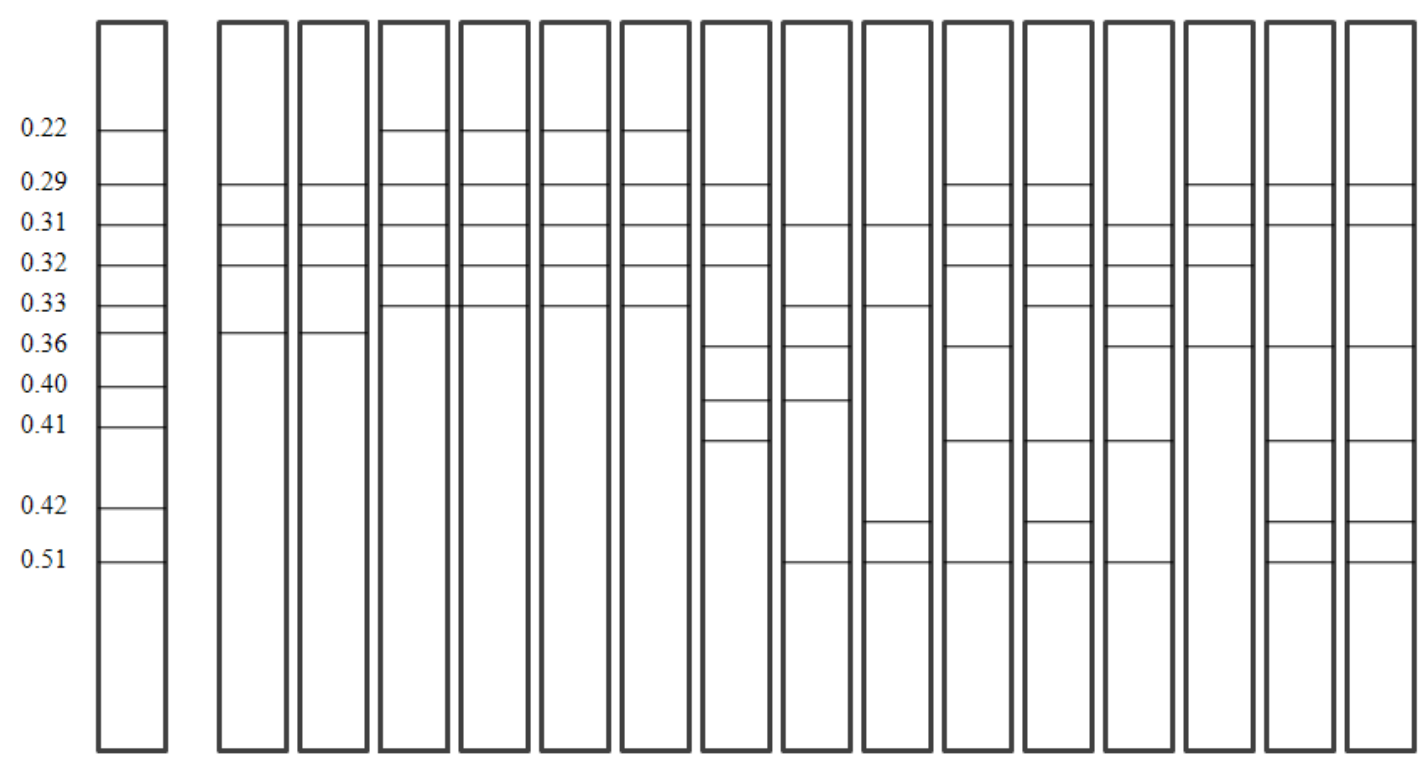

Fig.2 Dendrogram for Alpha esterase isozyme data, showing relationships among Alternaria spp

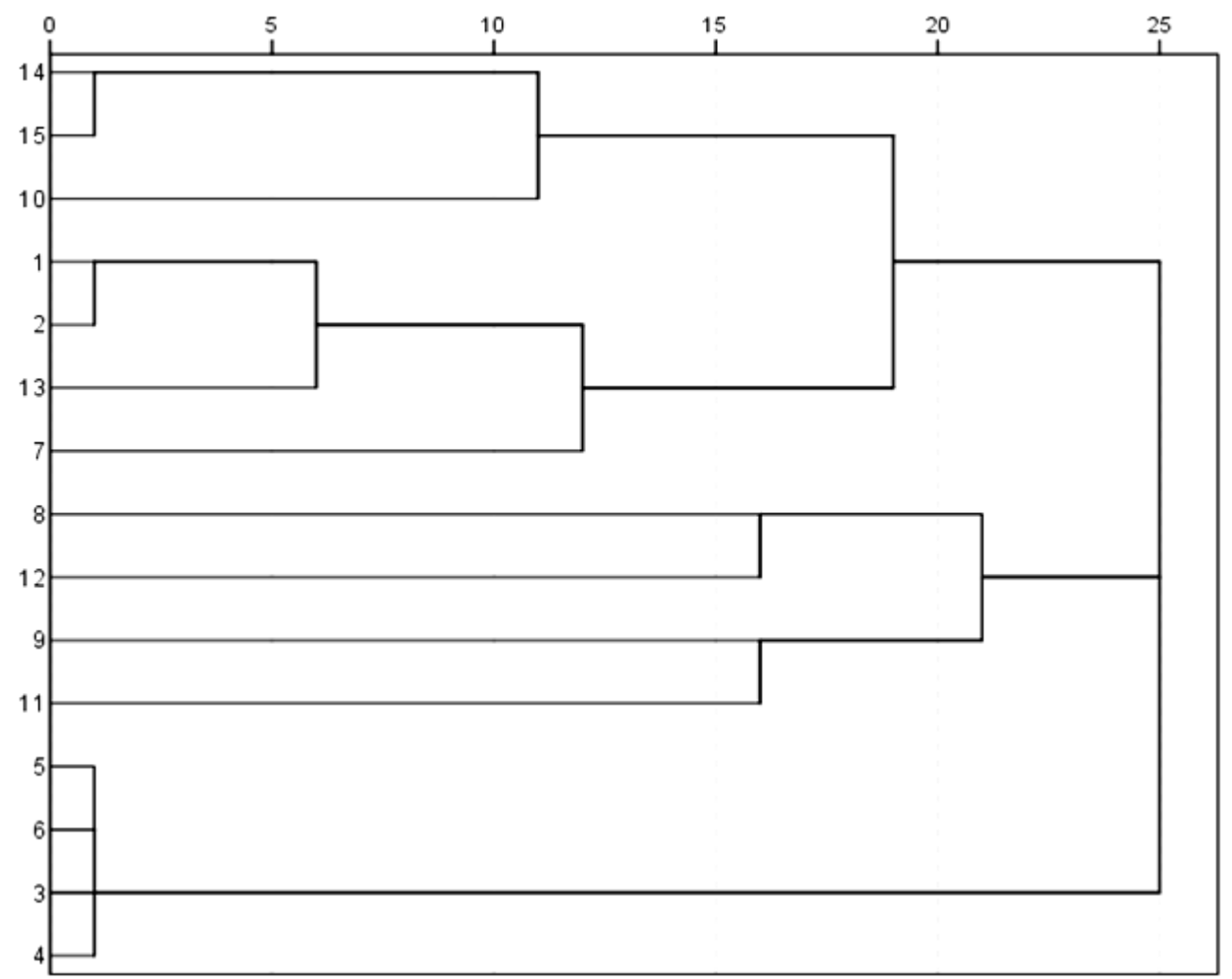

Dendrogram using Avarage Linkage (Between Groups) Rescaled distance cluster combine 
Fig.3 Zymogram of Beta esterase isozyme of Alternaria isolates

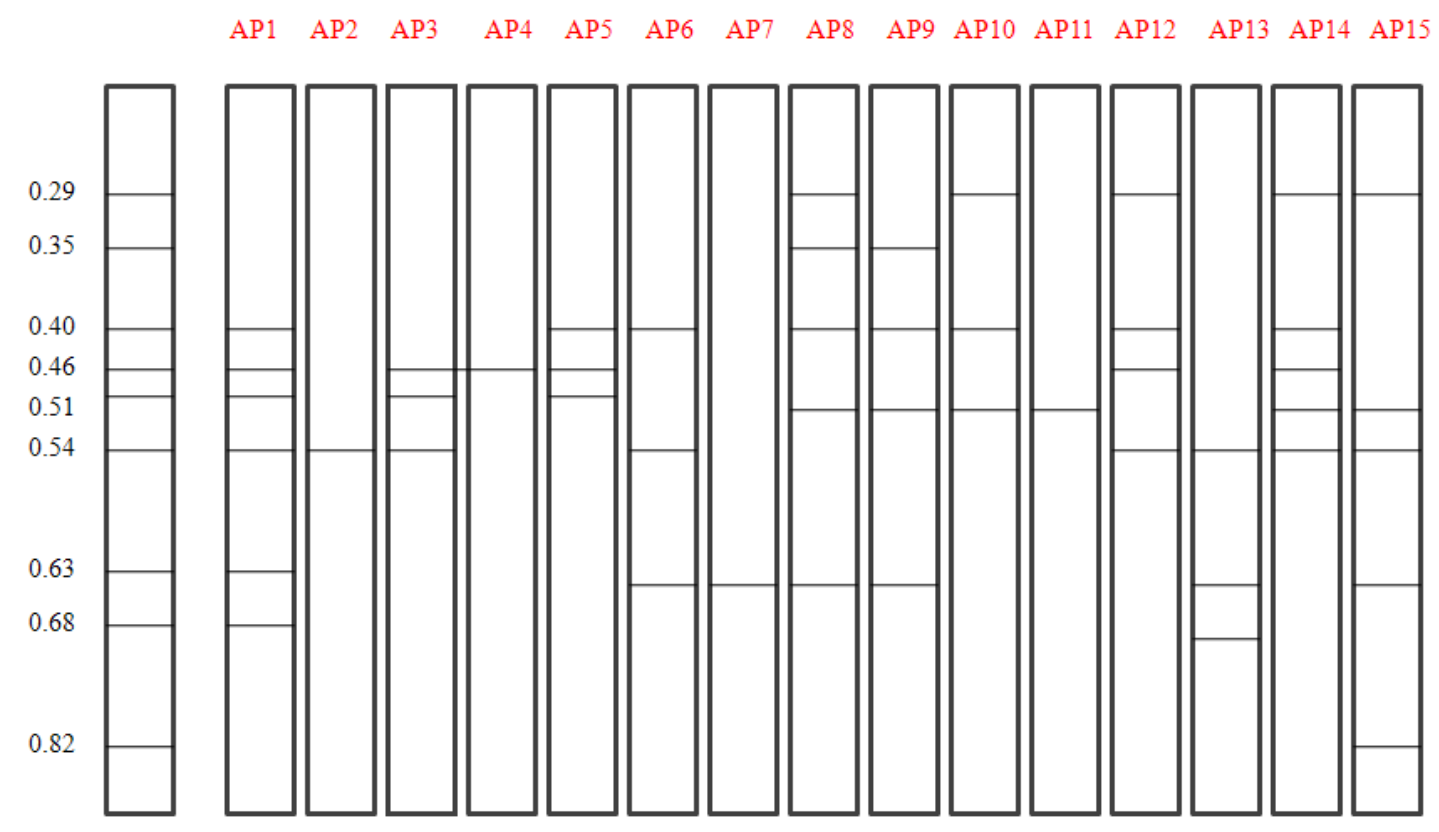

Fig.4 Dendrogram for beta esterase isozyme data, showing relationships among Alternaria spp

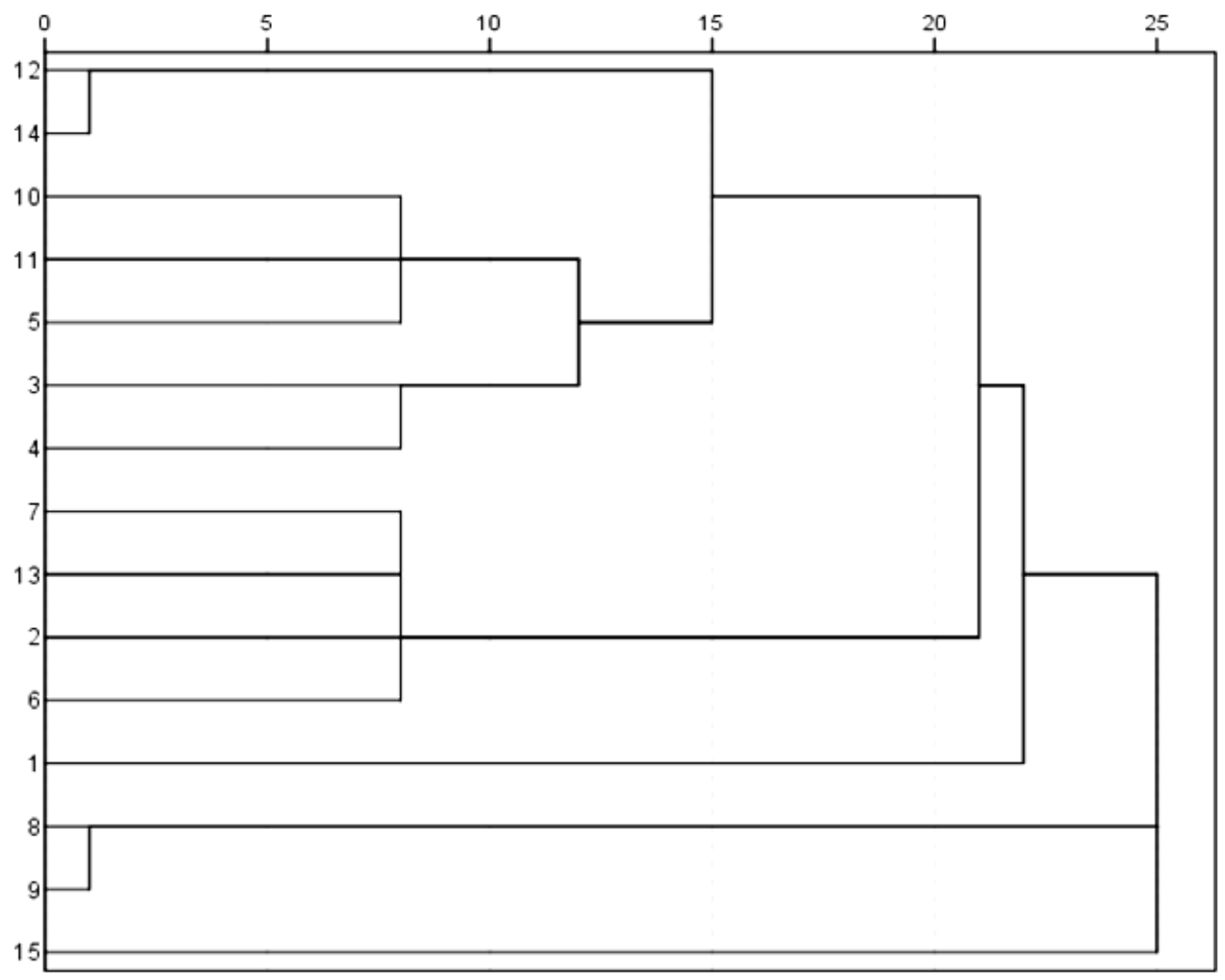




\section{Beta esterase isozyme}

A separate experiment was conducted to study the biochemical variability among Alternaria isolates collected from different locations based on $\beta$-esterase profiling.

All the isolates have different banding pattern and maximum locii 6 was observed on isolate $\mathrm{AP}_{1}$. Three isolate produced 5 banding patterns $\left(\mathrm{AP}_{8}, \mathrm{AP}_{14}\right.$ and $\left.\mathrm{AP}_{15}\right)$ and another five isolate produced 3 banding patterns $\left(\mathrm{AP}_{3}\right.$, $\mathrm{AP}_{5}, \mathrm{AP}_{6}, \mathrm{AP}_{10}$ and $\left.\mathrm{AP}_{13}\right)$. Two isolates produced 4 banding patterns $\left(\mathrm{AP}_{9}\right.$ and $\left.\mathrm{AP}_{12}\right)$ and four isolates produced 1 banding patterns $\left(\mathrm{AP}_{2}, \mathrm{AP}_{4}, \mathrm{AP}_{7}\right.$ and $\left.\mathrm{AP}_{11}\right)$. Among the 15 isolates, isolate $\mathrm{AP}_{15}$ produced one loci of highest $\mathrm{Rm}$ value of 0.82 . Five isolates $\left(\mathrm{AP}_{8}\right.$, $\mathrm{AP}_{10}, \mathrm{AP}_{12}, \mathrm{AP}_{14}$ and $\mathrm{AP}_{15}$ ) produced another loci of $\mathrm{Rm}$ value 0.29 and two isolates $\left(\mathrm{AP}_{8}\right.$ and $\mathrm{AP}_{9)}$ produced another $\mathrm{Rm}$ value of 0.35 . Among the 15 isolates, 8 isolates also produced another loci of $\mathrm{Rm}$ value of 0.40 except $\mathrm{AP}_{2}, \mathrm{AP}_{3}, \mathrm{AP}_{4}, \mathrm{AP}_{7}, \mathrm{AP}_{11}, \mathrm{AP}_{13}$ and $\mathrm{AP}_{15}$. Similarly the 9 isolates of among 15 isolates, also produced another loci of $\mathrm{Rm}$ value 0.51 except $\mathrm{AP}_{2}, \mathrm{AP}_{4}, \mathrm{AP}_{6}, \mathrm{AP}_{7}, \mathrm{AP}_{12}$ and $\mathrm{AP}_{13} .8$ isolates also produced another loci of $\mathrm{Rm}$ value of 0.54 except $\mathrm{AP}_{4}, \mathrm{AP}_{5}, \mathrm{AP}_{7}$, $\mathrm{AP}_{8}, \mathrm{AP}_{9}, \mathrm{AP}_{10}$ and $\mathrm{AP}_{11}$. Similarly the 7 isolates $\left(\mathrm{AP}_{1}, \mathrm{AP}_{6}, \mathrm{AP}_{7}, \mathrm{AP}_{8}, \mathrm{AP}_{9}, \mathrm{AP}_{13}\right.$ and $\mathrm{AP}_{15}$ ) of among 15 isolates, also produced another loci of $\mathrm{Rm}$ value 0.63 and 6 isolates $\left(\mathrm{AP}_{1}, \mathrm{AP}_{3}, \mathrm{AP}_{4}, \mathrm{AP}_{5}, \mathrm{AP}_{12}\right.$ and $\left.\mathrm{AP}_{14}\right)$ produced another bands on $\mathrm{Rm}$ value of 0.46 . The two isolates $\mathrm{AP}_{1}$ and $\mathrm{AP}_{13}$ also produced one loci of $R m$ value 0.68 . This indicated that these 15 isolates were different in isozyme pattern of B-esterase (Fig. 3).

A dendogram was generated by UPGMA clustering as presented in the Figure 4. This dendrogram identified three major clusters with $25 \%$ euclidean distance. One cluster (group I) comprised of twelve isolates $\mathrm{AP}_{12}, \mathrm{AP}_{14}, \mathrm{AP}_{10}, \mathrm{AP}_{11}, \mathrm{AP}_{5}, \mathrm{AP}_{3}$
$\mathrm{AP}_{4}, \mathrm{AP}_{7}, \mathrm{AP}_{13}, \mathrm{AP}_{2}, \mathrm{AP}_{6}$ and $\mathrm{AP}_{1}$ while other cluster (group II) comprised of two isolates $\mathrm{AP}_{8}$ and $\mathrm{AP}_{9}$ and another cluster (group III) comprised of only one isolate $\mathrm{AP}_{15}$. Group I was further sub-clustered into two groups, of which first sub-cluster (group IA) had eleven isolates and was again sub divided into two clusters, i,e group IAa and group IAb. Group IAa comprised of seven isolates $\mathrm{AP}_{12}, \mathrm{AP}_{14}, \mathrm{AP}_{10}, \mathrm{AP}_{11}, \mathrm{AP}_{5}, \mathrm{AP}_{3}$ and $\mathrm{AP}_{4}$ while isolates $\mathrm{AP}_{12}$ and $\mathrm{AP}_{14}$ shared very close relationship. Group IAb had four isolate $\mathrm{AP}_{7}, \mathrm{AP}_{13}, \mathrm{AP}_{2}$ and $\mathrm{AP}_{6}$ which were closely related with each other. Second sub-cluster (group IB) included only one isolate $\mathrm{AP}_{1}$ and was in separate individual cluster. Group II was comprised of two isolates $\mathrm{AP}_{8}$ and $\mathrm{AP}_{9}$ which were closely related with each other. Group III was comprised of only one isolate $\mathrm{AP}_{15}$ and was in separate individual cluster.

\section{References}

Chethana, B.S., Girija Ganeshan, Archana S. Rao and Bellishree, K. 2018. Morphological and Molecular Characterization of Alternaria Isolates Causing Purple Blotch Disease of Onion. Int.J.Curr.Microbiol.App.Sci. 7(04): 3478-3493

Cramer, C.S., 2000. Breeding and genetics of Fusarium basal rot resistance in onion. Euphytica 115: 159-166.

Davis, B.J. 1964. Disc electrophoresis. II. Methods and application to human serum proteins. Annals of the New York Academy of Sciences, 121: 404427.

Gupta, R.B.L., Pathak, V.N., 1998. Yield loss in onion due to purple blotch disease caused by Alternaria porri. Phytophylactica 20:21-23.

Gupta, R.P., Srivastava, V.K., Pandey, V.B., 1986. Control of Purple blotch disease of onion seed crop. Indian Phtopathology39:303-307. 
Kahler, A.L and Allard, R.W. 1970. Genetics of isozyme variants in barley. I. Esterases. Crop Sci., 10: 444-448.

Lakra, B.S., 1999. Development of purple blotch incited by A.porri and its losses in seed crop of onion (Allium cepa). Indian Journal of Agricultural sciences 69:145-Peever T.L., Su G., CarpenterBoggs L., Timmer L.W., 2004. Molecular systematics of citrusassociated Alternaria species. Mycologia 96: 119-134.

Ramjegathesh, R., Ebenezar, E.G., Muthusamy, M., 2011.Management of onion leaf blight by Alternaria alternata (FR.) Keissler by botanicals and bio-control agents. Plant Pathology Journal 10(4): 192-196.

Selvaraj, S. (1976). Onion: Queen of the kitchen. Kisan World, 3(12): 32-34.

Tripathi, M.K., Tiwari, S., Khare, U.K., 2008. In vitro selection for resistance against purple blotch disease of onion (Allium сера L.) caused by Alternaria porri. Biotechnology 7: 80-86.

Wendem, J.F.and Weeden, N.F. (1989). Visualisation and interpretation of plant isozymes, In: Isozymes in Plant Biology (Eds) Soltis, D.E. and Soltis, P.S., Dioseovides Press, USA, pp. 546.

\section{How to cite this article:}

Srujani Behera, Subrata Dutta and Srikanta Das. 2018. Identification of Biochemical Variation in Alternaria Isolates of Onion Plant. Int.J.Curr.Microbiol.App.Sci. 7(07): 32-39.

doi: https://doi.org/10.20546/ijcmas.2018.707.004 